\title{
Investigating the Effects of Islamic Banking Contracts on Economic Growth of Iran
}

\author{
Mohammad Javad Mohagheghniya, Faramarz Khalighi, Ahmad Bakhtiyari \\ Faculty of Management and Accounting, Allameh Tabataba'I University, \\ Dehkadeh-ye-Olympic, Tehran, Iran \\ E-mail address: mostafa.sargolzaee@gmail.com
}

\begin{abstract}
This paper has aimed to investigate the effects of Islamic banking loans thereby different contracts which are permitted by sharia on GDP of Iran during (2000 to 2010) with seasonal data. In this research for estimating the function of long run relation, we use $\mathrm{ARDL}^{1}$ and $\mathrm{VAR}^{2}$ approach .Result in the former case reveals that there is a meaningful and positive effect of contracts on GDP. It also shows that the Qard Hasan (beneficence loans) elasticity of GDP is significantly different from other contracts. As in long run Qard Hasanhas the most effect on GDP afterward participating contracts and direct investment (financing) and finally trading contracts has the least effect on GDP.While in the latter case results show that the impacts of a permanent shock to the growth rate of loans on economic growth are or so positive for all contracts. And that shock will be wasted after ten periods (seasons). The impact of structural shock to the loan on liquidity is positive but decreasing. According to the results we can declare that an increment in participating contracts and Qard Hasan would enhance the GDP and influence it positively. If we decrease the dependency of trading contracts and increase the participating contracts and Qard Hasan, economic growth won't necessarily decrease.
\end{abstract}

Keywords: Islamic baking; GDP; Islamic contracts; ARDL and VAR Approach

JEL Classification: E23, P24, E42

\section{INTRODUCTION}

Nowadays we cannot imagine the process of economic growth with no heed to banking development. With this persistent progression; banks are after the optimized profit. In conventional banking system, management should charge more interest rate to deposits in order to attract and increase the banking resource. While this increment is compensated by loans lent thereby more interest rate. In this way we can profess that the above banking system doesn't serve the real investment and actual sector of economics.

On the other hand, the Islamic banking system criterions reveal that loans through the supernumerary contracts (between bank and costumers) help the real investment. Because these criterions emphasize on contracts don't yield debt but they bring about the wage for Islamic banks. Moreover, it can be seen in the practical pattern that how stimulus such as

\footnotetext{
${ }^{1}$ Auto-regressive Distributed lags

${ }^{2}$ Vector Auto-regressive
} 
enhance of efficiency or reduce of liquidity loss risk and finally decrease of bankruptcy risk leads to persuade people to use Islamic banking services. As the result of this persuasion real investment stimulus change and this optimized banking resources allocation produces a new form of utility function and finally enhancement of economic growth.

This paper has aimed to response these questions, first identifying the long relation between Islamic banking loans and economic growth, then investigating fluctuation share of Islamic banking loans to justify fluctuation of economic growth and finally testing the effects of a permanent shock to loans on economic growth. For responding, we used ARDL and VAR approach. In the second part of this paper, we briefly review the literature. The econometric methodology is discussed in the third part. Section four reveals empirical results. Finally part five concludes the paper.

\section{LITERATURE REVIEW}

Abduh and Azimi Omar, 2012, studied the short and long run relevance between Islamic banking and economic development through Co-integration and ECM models in Indonesia (2003-2010). They concluded there is a meaningful long run relation between Islamic banking system and economic development. Furqani and Mulyany, 2009, studied the dynamic contrast between Islamic banking and economic growth in Malaysia through ECM model (1977-2005). The results reveal there is a mutual Granger casualty between fixed capital and Islamic banking boom. But then in the long run there is two-way relevance between fixed capital and Islamic banking and economic growth. Spears, 1991, showed that embryonic stages of bank system and financial intermediary enhancement in African countries cause the economic growth. Monge Naranjo \& Hall, 2003, investigated how companies in Costa Rica get to bank loans. They use Logit and Probit model .Finally with four equationsthey show that the access of bank credit and loans has a positive effect on employment and performance of those companies.

\section{RESEARCH METHODOLOGY}

This paper purposes to pursue the impacts of Islamic banking contracts on economic growth. So we choose relevant variables on economic growth along with loans according to theoretical foundations. We use gross domestic production as sign and index for economic growth and some independent variables such as Islamic contracts and also two controlling variables to estimate long term and ECM result through ARDL. To gain Impulse Response and Variance Decomposition function we use VAR method.

\section{1. ARLD Approach}

The spurious regression is for the sake of no stationary variables. In this situation, we must use methods which lead us to estimate accurate pattern.one of the best method consider the short dynamic reaction between variables (The Engle-Granger's method, 1987, suffer from lack of this feature) and doesn't have bias in estimation is ARDL. 


\section{2. Bound Testing for Co-integrating}

If we want to investigate and take for grant to long term relevance between variables, we must estimate model like 1-1 and use F-statistics calculated by Pesaran et al, 2001 .But the distribution of this relation is not standard.

$$
\begin{aligned}
& \Delta L O G(G D P)_{t}=\mu_{0}+\sum_{i=1}^{p} \lambda_{i} \Delta L O G(G D P)_{t-i} \\
& +\sum_{i=1}^{p} \varphi_{i} \Delta L O G(L I Q)_{t-i}+\sum_{i=1}^{p} \eta_{i} \Delta L O G(\text { Inch })_{t-i} \\
& +\sum_{i=1}^{p} \psi_{i} \Delta L O G(\text { participating })_{t-i} \\
& +\sum_{i=1}^{p} \theta_{i} \Delta L O G(G H A R Z)_{t-i} \\
& +\sum_{i=1}^{p} \Phi_{i} \Delta L O G(\text { Direct Inv })_{t-i}+\sum_{i=1}^{p} \beta_{i} \Delta L O G(T A X)_{t-i}+\phi_{1} L O G(G D P)_{t-1} \\
& +\phi_{2} L O G(L I Q)_{t-1}+\phi_{3} L O G(\text { Inch })_{t-1}+\phi_{4} L O G{\text { (participating })_{t-1}} \\
& +\phi_{5} L O G(G H A R Z)_{t-1}+\phi_{6} L O G(\text { Direct Inv })_{t-1}+\phi_{7} L O G(T A X)_{t-1} \\
& +\varepsilon_{t} \quad 1-1
\end{aligned}
$$

The null and aforesaid hypothesis will be as follows:

$\mathrm{H}_{0}=\emptyset_{1}=\emptyset_{2}=\emptyset_{3}=\emptyset_{4}=\emptyset_{5}=\emptyset_{6}=\emptyset_{7}=0$

$\mathrm{H}_{1}=\emptyset_{1} \neq 0, \emptyset_{2} \neq 0, \emptyset_{3} \neq 0, \neq \emptyset_{4} \neq 0, \emptyset_{5} \neq 0, \emptyset_{6} \neq 0, \emptyset_{7} \neq 0$

The calculated critical levels have two bottom and upper limits. If $\mathrm{F}$ statistics goes higher than the upper limit $\mathrm{H}_{1}$ (aforesaid hypothesis) asserts long term relation, will be accepted.

\section{EMPIRICAL RESULTS}

\section{1. Unit root test}

First of all, is to grant that all variables would become integrate by one differentiation (I (1)). So we use Augmented Dickey Fuller test.

Table 1. Unit Root Test.

\begin{tabular}{|c|c|c|c|c|}
\hline Variables & $\begin{array}{c}\text { Calculated } \\
\text { ADF } \\
\text { Level }\end{array}$ & Prob & $\begin{array}{c}\text { Calculated ADF } \\
\text { First Difference }\end{array}$ & Prob \\
\hline LOG(GDP) & -2.214555 & 0.46 & -12.18628 & 0.00 \\
\hline LOG(LIQUIDITY) & -1.973993 & 0.59 & -4.103272 & 0.01 \\
\hline LOG(TRADING) & -0.502141 & 0.97 & -5.593298 & 0.00 \\
\hline
\end{tabular}




\begin{tabular}{|c|c|c|c|c|}
\hline LOG(PARTICIPATING) & -2.100842 & 0.53 & -4.280898 & 0.00 \\
\hline LOG(QARD HASAN) & -2.350133 & 0.39 & -3.528467 & 0.04 \\
\hline LOG(DIRECT INVESTMENT) & -2.899099 & 0.17 & -7.417997 & 0.00 \\
\hline LOG(TAX REVENUE) & -0.499713 & 0.97 & -9.789470 & 0.00 \\
\hline
\end{tabular}

\section{2. Co-integration Test}

Table 1 reveals that all variables become (I (1)). Ipso fact we can use Pesaran et al F test. According to the result of co-integration test (with intercept and no trend) shown by Table 2, the calculated $\mathrm{F}$ is bigger than critical levels calculated by Pesaran. So $\mathrm{H}_{0}$ is rejected and long run relevance is accepted.

Table 2. F-Statistics Co-integration Test for Level Relationship.

\begin{tabular}{|c|c|c|c|c|}
\hline Calculated F-statistics & \multicolumn{2}{|c|}{ Level 97.5\% } & \multicolumn{2}{c|}{ Level 99\% } \\
\hline \multirow{2}{*}{6.02} & $\mathrm{I}(0)$ & $\mathrm{I}(1)$ & $\mathrm{I}(0)$ & $\mathrm{I}(1)$ \\
\cline { 2 - 5 } & 2.82 & 4.06 & 3.26 & 4.54 \\
\hline
\end{tabular}

\section{3. Estimating of coefficient} follows:

The pattern investigates the impacts of Islamic banking loans on GDP will be as

a) Long run relation:

$(\text { GDP })_{\mathrm{t}}=\mathrm{a}_{0}+\mathrm{a}_{1}$ LOG(Liquidity $)_{\mathrm{t}}+\mathrm{a}_{2} \mathrm{LOG}(\text { Trading })_{\mathrm{t}}+\mathrm{a}_{3} \mathrm{LOG}(\text { participation })_{\mathrm{t}}+$ $\mathrm{a}_{4} \mathrm{LOG}(\mathrm{Q} A R D \text { HASAN })_{\mathrm{t}}+\mathrm{a}_{5} \mathrm{LOG}(\text { Direct Investment })_{\mathrm{t}}+\mathrm{a}_{6} \mathrm{LOG}(\text { Tax Income })_{\mathrm{t}}+\varepsilon_{t}$

b) Error Correction Model (ECM):

$$
\begin{aligned}
\Delta L O G(G D S P)_{t} & =\mu+\sum_{i=1}^{p} \lambda_{i} \Delta L O G(G D P)_{t-i} \\
& +\sum_{i=1}^{p} \alpha_{i} \Delta L O G(\text { Trade })_{t-i} \\
& +\sum_{i=1}^{p} \psi_{i} \Delta L O G(\text { participation })_{t-i}+\sum_{i=1}^{p} \beta_{i} \Delta L O G(\text { QARD HASAN })_{t-i} \\
& +\sum_{i=1}^{p} \gamma_{i} \Delta L O G(D I R E C T \text { INV })_{t-i}+\sum_{i=1}^{p} \eta_{i} \Delta L O G(L I Q)_{t-i} \\
& +\sum_{i=0}^{n} \theta_{i} \Delta L O G(T A X)_{t-i}+\varepsilon_{t}
\end{aligned}
$$


Table 3 shows succinctly that all Islamic banking contracts elasticity is positive in long run so that the Qard Hasan elasticity of GDP is significantly different from other contracts .As in long run Qard Hasan has the most effect on GDP afterward participating contracts and direct investment and finally trading contracts has the least effect on GDP. Moreover according to ECM results, we can proclaimthat economic growth is influenced by growth of contracts (first difference of variables). It means effects of loans on GDP don't rely on merely current period of contracts. ${ }^{3}$

Table 3. ARDL results $(4,2,4,4,3,4,4)$.

\begin{tabular}{|c|c|c|c|c|c|}
\hline \multicolumn{3}{|c|}{$\begin{array}{l}\text { LONG RUN Coefficient, Dependent Variable: } \\
\qquad \log (\text { GDP })\end{array}$} & \multicolumn{3}{|c|}{ ECM RESULTS } \\
\hline Variables & Coefficient & T-Value & Variables & Coefficient & T-Value \\
\hline LOG(Liquidity) & -0.99891 & -2.3493 & DLQARD HASAN $^{4}$ & 0.64123 & 2.9571 \\
\hline LOG(Tax) & 0.34366 & 2.1987 & DLQARD HASAN1 & -0.72791 & -2.4218 \\
\hline LOG(Trading) & 0.15424 & 2.1941 & DLtrading $1^{5}$ & 0.48397 & 2.5930 \\
\hline LOG(participating) & 0.31895 & 2.3296 & DLparticipating 1 & -1.1087 & -3.3788 \\
\hline LOG(Direct Inv) & 0.30762 & 2.6412 & DLparticipating 2 & -0.41648 & -2.1048 \\
\hline LOG(QARD HASAN) & 0.62311 & 4.7639 & DLparticipating 3 & -0.76045 & -3.9090 \\
\hline Intercept & 8.1701 & 5.1400 & DL Direct Inv 1 & -0.29446 & -3.0199 \\
\hline \multirow{2}{*}{\multicolumn{3}{|c|}{ Diagnostic Test }} & DL Direct Inv 2 & -0.22910 & -2.5556 \\
\hline & & & DLLiq & 0.54866 & 0.63791 \\
\hline R-Squared & \multirow{3}{*}{\multicolumn{2}{|c|}{$\begin{array}{c}99 \% \\
96 \% \\
40.81(0.000)\end{array}$}} & DLTax & 0.46176 & 4.9937 \\
\hline R-Bar-Squared & & & $\mathrm{D}$ (Intercept) & 12.6518 & 3.1774 \\
\hline F-Stat & & & $\operatorname{ECM}(-1)$ & -1.5485 & -3.6988 \\
\hline
\end{tabular}

\section{VAR APPROACH}

The vector autoregression (VAR) is commonly used for forecasting systems of interrelated time series and for analyzing the dynamic impact of random disturbances on the system of variables. The main goal for estimating of this approach is to gain impulse response and variance decomposition functions (IRF and VDF). Therefore we use first difference of variables (stationary mode). First of all we must compute various criteria to select the lag order of an unrestricted VAR. Schwarz information criteria shows optimized lag is one. Before estimating, some tests must be put to the test

\footnotetext{
${ }^{3}$ Those variables which are not meaningful are not reported.

4 dLGHARZ = LGHARZ-LGHARZ $(-1)$

${ }^{5} \mathrm{dL}$ trading $1=\operatorname{Ltrading}(-1)-\operatorname{Ltrading}(-2)$
} 


\section{1. Pairwise Granger Causality Test}

It tests whether an endogenous variable can be treated as exogenous. The table is for testing the null hypothesis that the coefficients of the lagged values in the block of equations explaining the variables are zero.

Table 4. Shows that we can reject $\mathrm{H}_{0}$.

\begin{tabular}{|c|c|c|}
\hline level of significance & Prob & Calculated statistics \\
\hline 95 & 0.02 & 14.8347 \\
\hline
\end{tabular}

\section{2. VAR Stationary}

The estimated VAR is stable (stationary) if all roots have modulus less than one and lie inside the unit circle. If the VAR is not stable, certain results (such as impulse response standard errors) are not valid.

\section{Inverse Roots of AR Characteristic Polynomial}

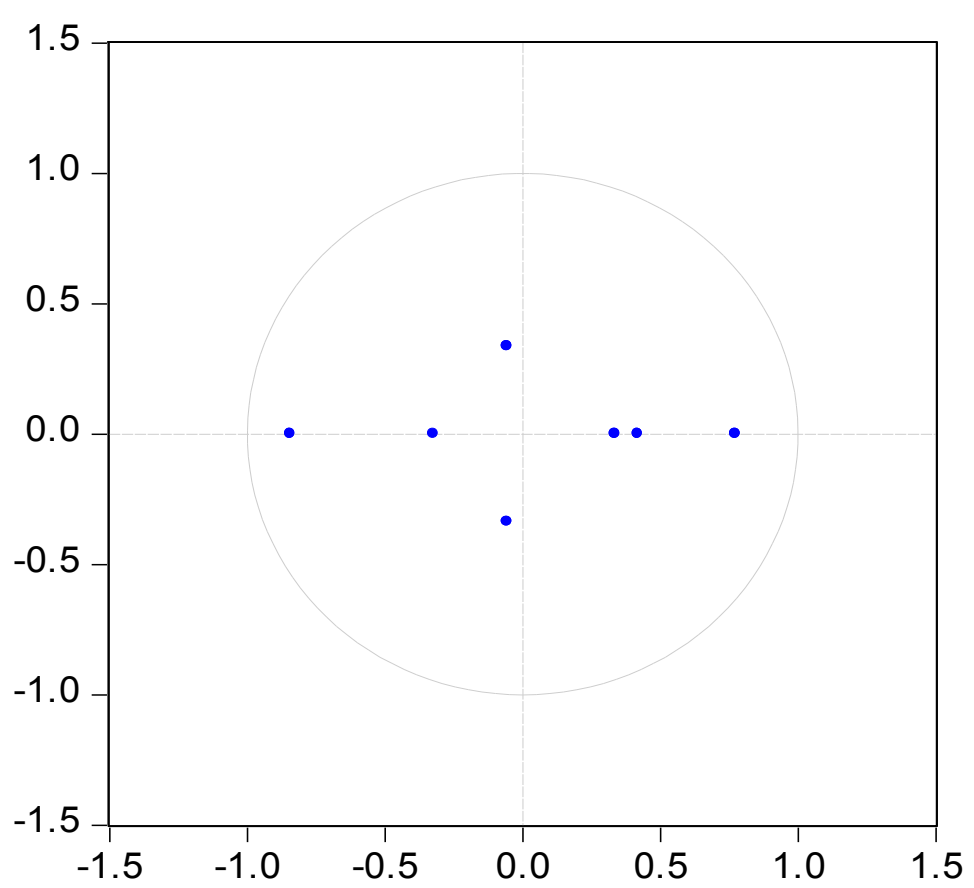

Figure 1. Shows that our VAR is stable. Now we can claim that our model is valid and reliable. So we can calculate IRF and VDF. 


\section{3. Generalized Impulse Responses}

A shock to the i-th variable not only directly affects the i-th variable but is also transmitted to all of the other endogenous variables through the dynamic (lag) structure of the VAR.

Response to Generalized One S.D. Innovations \pm 2 S.E.

Response of DLGDP to DLDIRECTINVETMENT

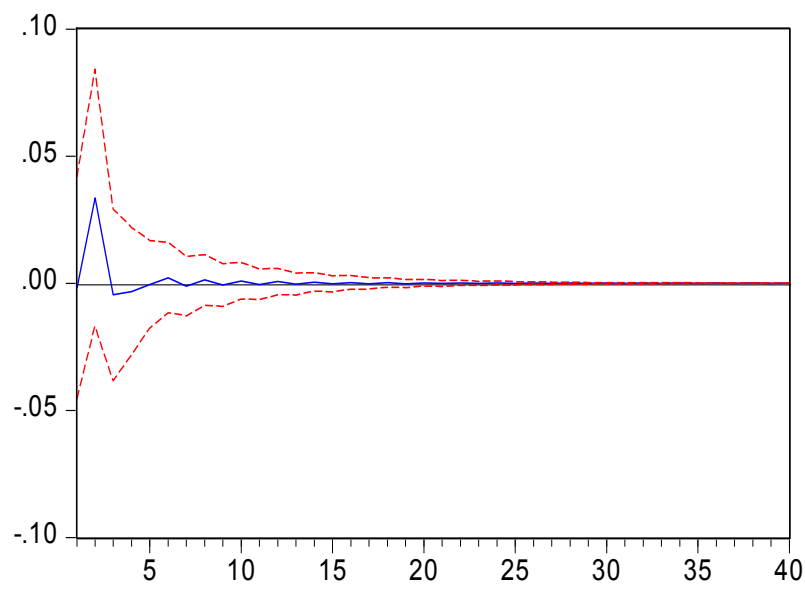

Response of DLGDP to DLQARDHASAN

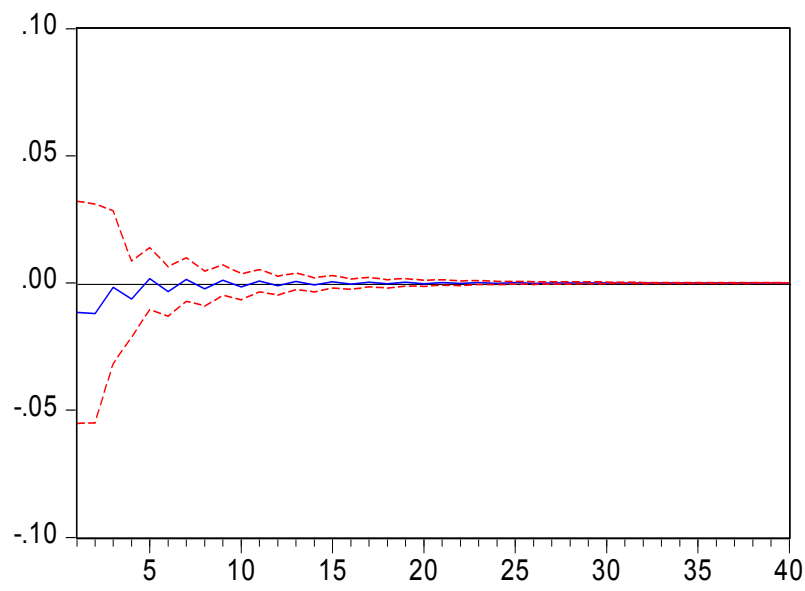

Response of DLGDP to DLPARTICIPATING

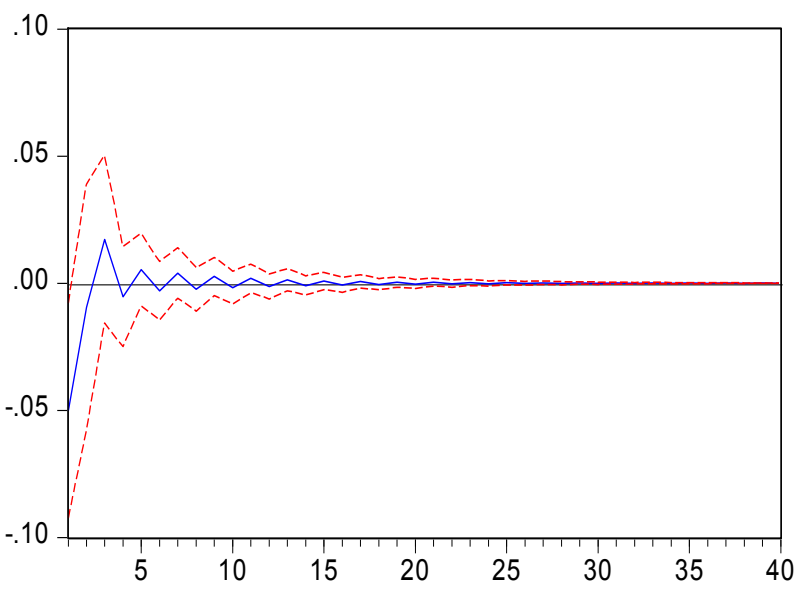

Response of DLGDP to DLTRADING

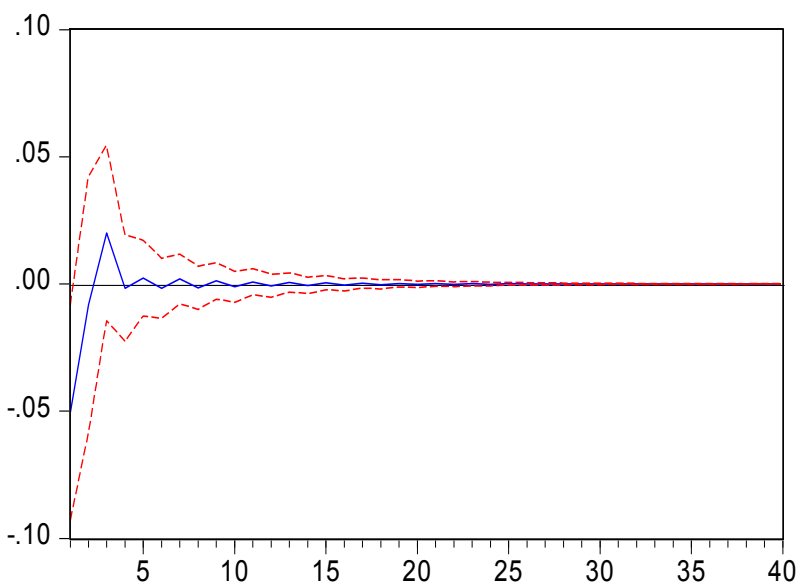

Figure 2.

An impulse response function traces the effect of a one-time shock to one of the innovations on current and future values of the endogenous variables. We set the impulses to Generalized Impulses. As described by Pesaran and Shin (1998) constructs an orthogonal set of innovations that does not depend on the VAR ordering. Figure 2 shows effects of a permanent shock to the growth rate of loans (Trade, Participating, Direct Investment and Qard Hasan) on economic growth for 40 periods.

In brief, the impulse response analysis suggests that growth of Islamic contracts have a positive and significant effect on economic growth with high persistence (about ten seasons). 
Figure 3 shows effects of a permanent shock to the growth rate of loans on liquidity growth for 40 periods.

In brief, Figure 3 shows that growth of Islamic contracts has a negative and significant effect on liquidity growth especially participating contracts.

Response to Generalized One S.D. Innovations \pm 2 S.E.

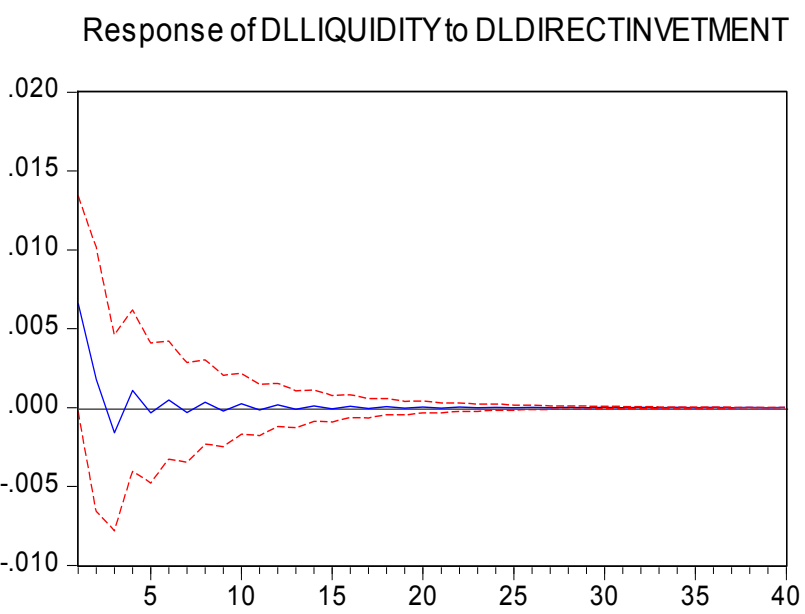

Response of DLLIQUIDITY to DLPARTICIPATING

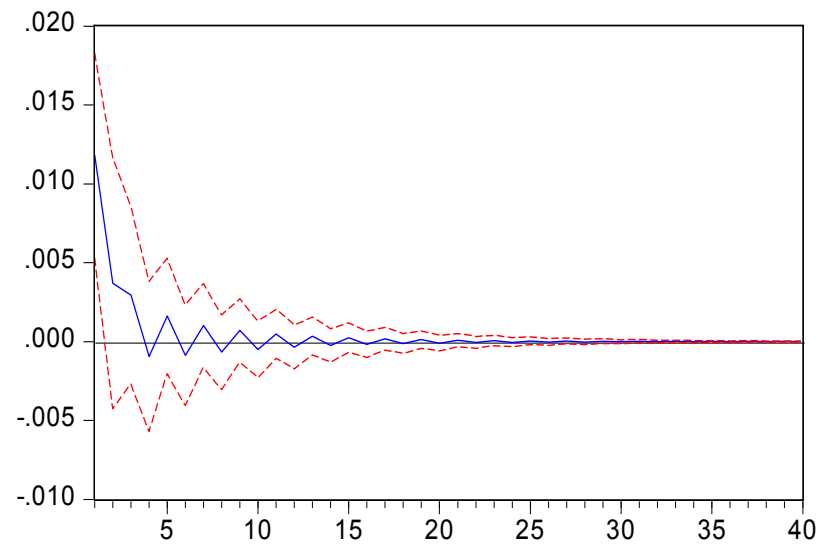

Response ofDLLIQUIDITY to DLQARDHASAN

Response of DLLIQUIDITY to DLTRADING
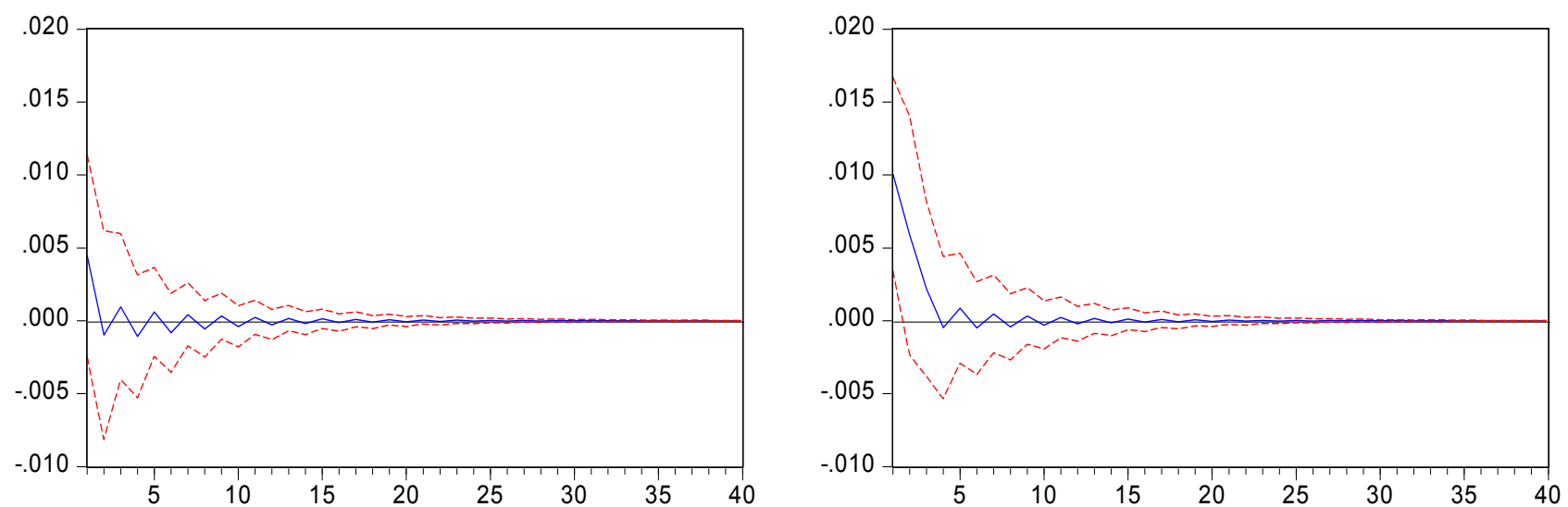

Figure 3.

\section{4. Generalized Variance Decomposition}

While impulse response functions trace the impacts of a shock to one endogenous variable on to the other variables in the VAR, variance decomposition separates the variation in an endogenous variable into the component shocks to the VAR. table 5 shows the generalized variance decomposition for three years (12 seasons). It also shows 70-100 percentage of economic growth fluctuation is explained by itself. But trade and participating contracts have a prominent share of this explanation. 
Table 5. Generalized Variance Decomposition Of DLOG (GDP).

\begin{tabular}{|c|c|c|c|c|c|c|c|}
\hline HORIZON & DLGDP & $\begin{array}{c}\text { DL } \\
\text { Participating }\end{array}$ & $\begin{array}{c}\text { DLQard } \\
\text { Hasan }\end{array}$ & $\begin{array}{c}\text { DLDirect } \\
\text { Invest }\end{array}$ & DLTax & $\begin{array}{c}\text { DL } \\
\text { Liquidity }\end{array}$ & $\begin{array}{c}\text { DL } \\
\text { Trading }\end{array}$ \\
\hline 0 & 1.000 & 0.12534 & 0.0067216 & $0.1761 \mathrm{E}-3$ & $0.2150 \mathrm{E}-3$ & 0.09666 & 0.12720 \\
\hline 1 & 0.82343 & 0.10696 & 0.0011467 & 0.046633 & 0.15890 & 0.07967 & 0.10752 \\
\hline 2 & 0.76217 & 0.10735 & 0.010431 & 0.042789 & 0.20376 & 0.10943 & 0.11161 \\
\hline 3 & 0.73598 & 0.10452 & 0.011493 & 0.041651 & 0.21377 & 0.12334 & 0.10774 \\
\hline 4 & 0.71939 & 0.10311 & 0.011330 & 0.040713 & 0.22303 & 0.13005 & 0.10548 \\
\hline 5 & 0.70803 & 0.10178 & 0.011548 & 0.040222 & 0.22997 & 0.13393 & 0.10391 \\
\hline 6 & 0.69981 & 0.10111 & 0.011474 & 0.39793 & 0.23519 & 0.13694 & 0.10280 \\
\hline 7 & 0.69427 & 0.10050 & 0.011552 & 0.039525 & 0.23845 & 0.13911 & 0.10206 \\
\hline 8 & 0.69031 & 0.10015 & 0.011524 & 0.039315 & 0.24089 & 0.14056 & 0.10151 \\
\hline 9 & 0.68758 & 0.099858 & 0.011556 & 0.039184 & 0.24251 & 0.14162 & 0.10115 \\
\hline 10 & 0.68563 & 0.099682 & 0.011545 & 0.039081 & 0.24372 & 0.14233 & 0.10087 \\
\hline 11 & 0.68427 & 0.099537 & 0.011558 & 0.039016 & 0.24453 & 0.14286 & 0.10069 \\
\hline 12 & 0.68329 & 0.099448 & 0.011554 & 0.038965 & 0.24513 & 0.14322 & 0.10056 \\
\hline
\end{tabular}

\section{CONCLUSION}

The empirical results on long term relation and ECM (through ARDL) have emphasized that the economic growth is effected by Islamic banking loans and also show that the Qard Hasanelasticity of GDP is significantly different from other contracts .As in long run Qard Hasan has the most effect on GDP afterward participating contracts and direct investment and finally trading contracts has the least effect on GDP.VAR results show that these loans has positive effect to economic growth but negative to liquidity. So it grants the strength of Islamic banking operation.It means Islamic banking has some perfect tools in order not to lose and be bankrupt. In brief it can help economy to improve. Hereby Islamic banking causes to happen HARMONY OF INTEREST.

\section{Reference}

[1] Guglielmo Maria Caporale, Stefano Di Colli, Juan Sergio Lopez, Bank Lending Procyclicality and Credit Quality During Financial Crises, Economics and Finance Working Paper Series, (June 2013).

[2] Hashem Pesaran, Yongcheol Shin, Generalized Impulse Response Analysis in Linear Multivariate Models, (July 199) 7.

[3] Helmut Lütkepohl, Markus Krätzig, Dmitri Boreiko, VAR Analysis in JMulTi, (January 2006). 
[4] Kuala Lumpur J.A., A. Semantan, Islamic Banking Handboo', Published by Institut Bank-Bank Malaysia, First Edition (April 2010).

[5] Magnus von Schéele, Islamic Banking Law Concept, practice \& effects, Faculty of Law, University of Lund, (October 2002).

[6] Markku Lanne, Henri Nyberg, Generalized Forecast Error Variance Decomposition for Linear and Nonlinear Multivariate Models, Department of Economics and Business Aarhus University, (May 2014).

[7] Mongenaranjo Alexander, Lasinj Hallu, Access to credit and the effect of credit consrants on costarican manufacturing firmsfebruang, working paper (2003).

[8] Mohammadreza Monjazeb, Reza Nosrati, Effects of banking facilities on employment trends in selected provinces of Iran, Asian Journal of Research in Business Economics and Management 4(5) (2014).

[9] Mohsen Mehrara, Mostafa Sargolzaei, Razieh Ahmadi, Marzieh Ahmadi, Investigating the Relation between Financial Development and Economic Growth Using ARDL Approach, Journal of Basic and Applied Scientific Research (2012).

[10] Muhammad Hanif, Differences and Similarities in Islamic and Conventional Banking, International Journal of Business and Social Science 2(2) (2011).

[11] Saeedi A., Moghadasian I., Stock Exchange Quarterly 9 (2010) 5-24.

[12] Mohsen Mehrara, Hamid Abrishami, Mostafa Boroujli, Mahan Amin, International Letters of Social and Humanistic Sciences 11 (2013) 76-83.

[13] Bahram Meihami, Zeinab Varmaghani, Hussein Meihami, International Letters of Social and Humanistic Sciences 11 (2013) 91-99.

[14] Mohsen Mehrara, Zabihallah Falahati, Nazi Heydari Zahiri, International Letters of Social and Humanistic Sciences 10(1) (2014) 26-35.

[15] Morteza Ziaee, International Letters of Social and Humanistic Sciences 10(1) (2014) 36-43.

[16] Gholamreza Jandaghi, Hamid Reza Irani, Ehssan Jandaghi, Zeinab Sadat Mousavi, Maryam Davoodavabi, International Letters of Social and Humanistic Sciences 15(1) (2014) 78-83.

[17] Mohammadbagher Mohammadinejad Pashaki, Reza Tehrani, Hamid Zarea, Hossein Khanifar, Gholamreza Jandaghi, International Letters of Social and Humanistic Sciences 18 (2014) 8-13.

[18] Sasan Amini, Mohammad Nazaripour, Mohamad Karimi Poya, International Letters of Social and Humanistic Sciences 29 (2014) 82-94. 